\title{
Quality of Life on the Colorado Plateau: \\ A Report to Respondents in \\ Southwestern Colorado and Northwestern New Mexico
}

\author{
By \\ Phadrea D. Ponds \\ U.S. Geological Survey \\ Midcontinent Ecological Science Center
}

Open File Report 01-233

2001

This report has not been reviewed for conformity with the U.S. Geological Survey editorial standards. Any use of trade, product or firm names is for descriptive purposes and does not imply endorsement by the U.S. Government. 


\section{Contents}

Page

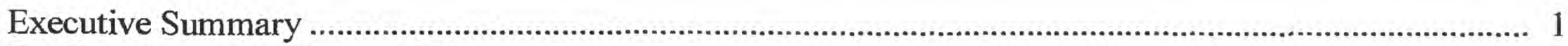

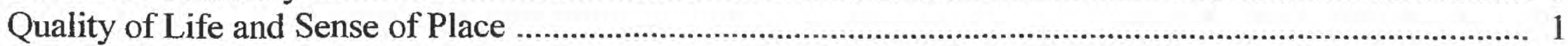

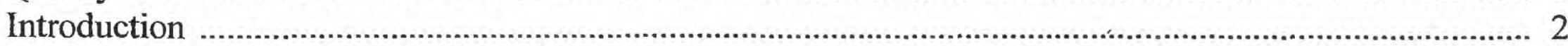

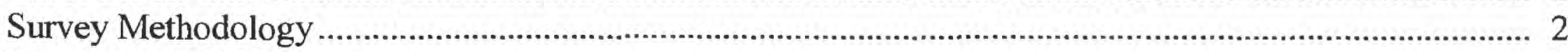

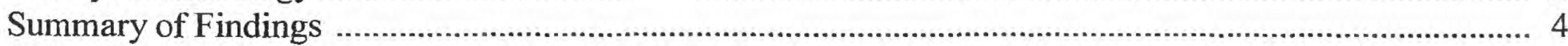

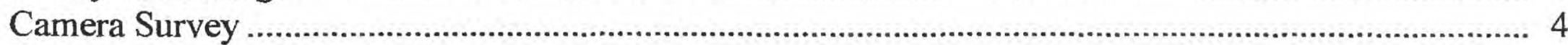

Positive and Negative Effects on Quality of Life ........................................................................... 7

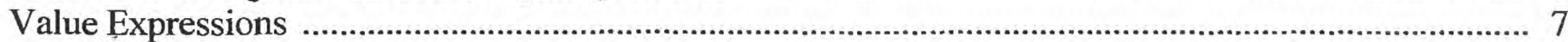

Summary of Findings from Follow-Up Survey: Resident Satisfaction with their Community ....................11

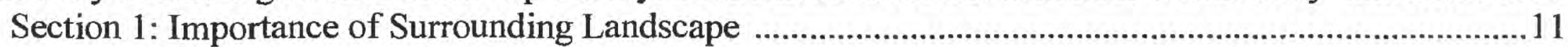

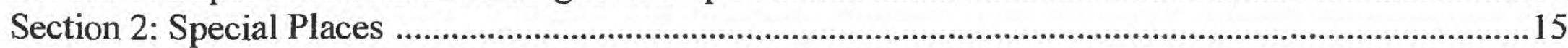

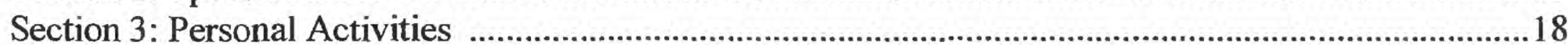

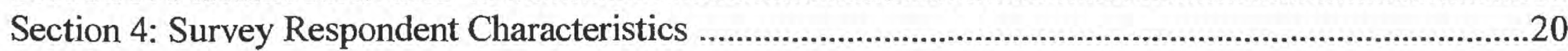

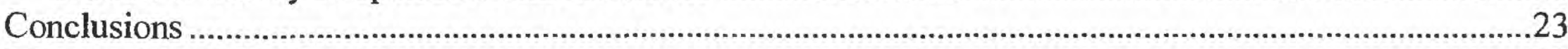

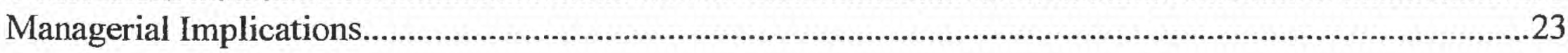




\section{Quality of Life in Southwestern Colorado and Northwestern New Mexico}

\section{Executive Summary}

This report presents of the survey findings from a mail-out camera survey (completed March 9, 1999). Residents of southwestern Colorado and northwestern New Mexico were asked to take photographs and describe elements of their community that affected their quality of life. Residents of this area were randomly selected. Several findings reported by the respondents are worthy of special attention:

- Open space and vista views: One hundred and eight $(12.7 \%)$ of the photographs taken by the respondents suggested that various landscape views were very important to people's quality of life. The landscape views included mountains, cliffs, rock formations, valleys, and pastures. Photographs that showed how respondents could observe the "wonder of nature" and unobstructed views -- where they "could see for miles" were considered the most positive aspect of living in the area.

- Water: Sixty-two percent of the photos were taken of various bodies of water. The Animas River was the most frequently photographed water body. This river, in combination with the variety of recreational opportunities it offered, seemed to make a considerable contribution to the quality of life of the residents.

- Community aesthetics and family values: Sixty-six (8\%) of the photographs depicted amenities that showed respondents or family members interacting in a family-oriented activity (e.g. camping, hiking, or kids playing in the park or backyard).

- Housing: Fifty-four (76\%) of the 71 photos taken of houses or housing communities resulted in a negative response. The explanations ranged from "poor use of land," "too many multimillion dollar homes in this area," to "slummy, run down, low income housing."

In general, the results showed that these residents are people who value the aesthetic amenities of the surrounding landscapes. Comments such as "I love this view from my back yard," and "there's no place better than this on Earth," suggest that residents view nature and the environment as an important part of their everyday life. However, they were also very much aware of some of the detrimental effects that growth and development are having on their community, but at the same time they were able to recognize the balance between the need for economic growth and the survival of their small town communities. The overall desire was that growth would not come at the expense of their quality of life.

\section{Quality of Life and Sense of Place}

Howe et al. ${ }^{1}$ suggested that "quality of life" is a catchall term used to describe the non-economics amenities a community has to offer, including clean air, water, safe streets, open spaces, recreational opportunities, uncongested roads good schools and scenic views. According to Galliano and Loeffler ${ }^{2}$, the term "sense of place" is a holistic concept that focuses on the subjective and often shared experience or attachment to the landscape that is either emotional or symbolical. "Sense of place" refers to the perception that people have of a physical area with which they interact. ${ }^{3}$

\footnotetext{
${ }^{1}$ Howe, J., E. McMahon, and L. Propst. 1997. Balancing nature and commerce in gateway communities. Island Press, Washington, D.C.

${ }^{2}$ Galliano, S. J., and G. M. Loeffler. 1999 . Place assessment: how people define ecosystems. General Technical Report PNWGTR-462. Portland, OR: U.S. Department of Agriculture, Forest Service, Pacific Northwest Research Station. 31 p.

${ }^{3}$ ibid
} 
The survey we conducted focused on the aspects of the landscape on the Colorado Plateau that contribute to the quality of life and sense of place for the local residents. The results from this study will aid natural resource agencies in their evaluation of current land management practices. This study attempted to assist natural resource managers in making informed decisions about the development of future management plans and practices that will impact local communities and their residents.

\section{Introduction}

During the fall of 1998, scientists from the Midcontinent Ecological Science Center (MESC) of the U.S. Geological Survey (USGS) - sent a survey ${ }^{4}$ by mail to residents in southwest Colorado and northwest New Mexico to better understand quality of life issues in this area of the Colorado Plateau. Collaborators in the study included the Bureau of Land Management and U.S. Forest Service offices located in Durango, Colorado. The information was collected to determine:

what elements of the community and surrounding landscapes contribute to the quality of life among resident populations, and

* what critical areas, elements, and special places are essential to retain a certain quality of life.

\section{Survey Methodology}

We obtained addresses for 600 residents $^{5}$ of a six county area including: San Juan (CO), and Delores, Montezuma La Plata Archuleta counties in Colorado and San Juan County In New Mexico (Figure 1). These potential respondents were randomly sampled from the towns in each of the counties within the study area (Table 1).

Table 1. Listing of counties and towns in which the sample communities are located.

\begin{tabular}{|l|l|l|l|l|l|}
\hline $\begin{array}{c}\text { San Juan } \\
\text { (CO) } \\
\mathrm{n}=21\end{array}$ & $\begin{array}{l}\text { Dolores } \\
\mathrm{n}=12\end{array}$ & $\begin{array}{l}\text { Montezuma } \\
\mathrm{n}=103\end{array}$ & $\begin{array}{l}\text { La Plata } \\
\mathrm{n}=148\end{array}$ & $\begin{array}{l}\text { Archuleta } \\
\mathrm{n}=19\end{array}$ & $\begin{array}{l}\text { San Juan (NM) } \\
\mathrm{n}=297\end{array}$ \\
\hline \begin{tabular}{|l|l|l|l|} 
Silverton (11) \\
Telluride (10)
\end{tabular} & $\begin{array}{l}\text { Dove Creek } \\
(12)\end{array}$ & $\begin{array}{l}\text { Cortez (75) } \\
\text { Dolores (14) } \\
\text { Lewis (1) } \\
\text { Mancos (12) } \\
\text { Pleasant View } \\
(1)\end{array}$ & $\begin{array}{l}\text { Bayfield (21) } \\
\text { Durango (114) } \\
\text { Hesperus (5) } \\
\text { Ignacio (8) }\end{array}$ & $\begin{array}{l}\text { Chimney Rock (2) } \\
\text { Pagosa Springs } \\
(17)\end{array}$ & $\begin{array}{l}\text { Aztec (52) } \\
\text { Blanco (3) } \\
\text { Bloomfield (48) } \\
\text { Farmington (166) } \\
\text { Flora Vista (8) } \\
\text { Fruitland (2) } \\
\text { Kirtland (10) } \\
\text { La Plata (3) } \\
\text { Navajo Dam (1) } \\
\text { Shiprock (1) } \\
\text { Waterflow (2) } \\
\text { Nageezi (1) }\end{array}$ \\
\hline
\end{tabular}

${ }^{4}$ OMB Control Number: 1028-0067.

${ }^{5}$ The names and addresses were provided by Survey Sampling Inc., a national marketing research company, which compiles names and addresses from residential telephone directories, cross-checked by automobile registrations and national change of address files released monthly by the U.S. Postal Service. 


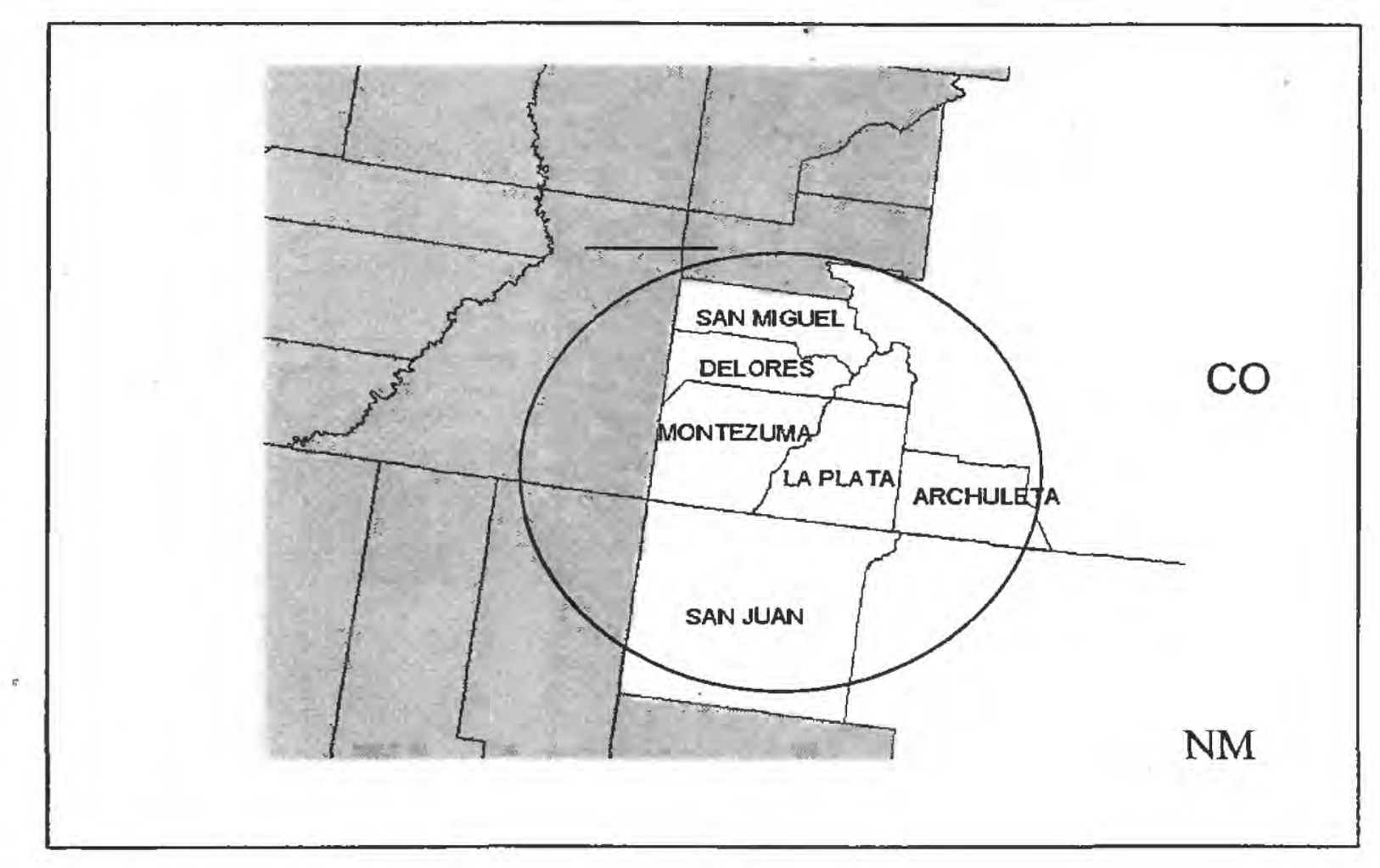

Figure 1. Map of SCNNM study area.

Those residents participating in the study received a single-use camera and were asked to record via photography and written record (photo-log) those activities, elements, or areas of their community and surrounding county that affect their quality of life. For each photograph, respondents were asked to record in the photo-log what was photographed, where the photograph was taken, whether the affect on their quality of life was positive or negative, and their rationale for taking the photograph.

Once the cameras (including the film) and photo-logs were returned to the MESC, the photographs were developed (duplicate sets were made). One set of pictures was mailed to the respondent along with a follow-up survey, and the second set was retained at the MESC by the research team. The follow-up survey included standard demographic questions, as well as questions that would illicit detailed and descriptive responses concerning the photographs. Additional questions were related to quality of life, community uniqueness, and personal perception/preferences.

Each respondent received a blank mailing label where they were able to supply a mailing address in order to request the results of the survey. Records of those requesting results from the study, were kept separately from the survey data to ensure complete confidentiality of the respondents. No record was kept that would connect any individual respondent with the survey data.

Before the initial mailing of the survey, a postcard was sent to potential respondents to: (1) alert potential respondents of survey, (2) determine undeliverable addresses in the sample, and (3) reduce the cost of the cameras being lost in the mail or undeliverable. We anticipated an $18 \%$ undeliverable rate due to death, relocation, etc. One hundred and seventy-two postcards $(29 \%)$ were returned as undeliverable. Four hundred and twenty-eight cameras were mailed to "usable" remaining addresses. Of those addresses 88 $(21 \%)$ residents declined to take part in the study, $123(36 \%)$ completed and returned the cameras and photo $\log$. One hundred and five of the $123(85 \%)$ respondents completed and returned the follow-up survey (Table 2). 
Table 2. Response rate for camera and follow-up survey.

\begin{tabular}{|l|c|}
\hline \multicolumn{1}{|c|}{ Responses } & Overall \\
\hline Number of addresses & 600 \\
\hline Number of undeliverable addresses & 172 \\
\hline Adjusted sample & 428 \\
\hline Refusals & 88 \\
\hline $\begin{array}{l}\text { Number of responses } \\
\text { Camera and photo log } \\
\text { Follow-up survey }\end{array}$ & 123 \\
\hline $\begin{array}{l}\text { Response rate (percent) } \\
\text { Camera and photo log } \\
\text { Follow up survey }\end{array}$ & 105 \\
\hline
\end{tabular}

The results of the camera survey and follow-up survey are presented below. A summary of key findings is presented followed by Tables containing the results of the analysis.

\section{Summary of Findings}

\section{Camera Survey}

The respondents were asked to record the following elements in their photo logs about each picture:

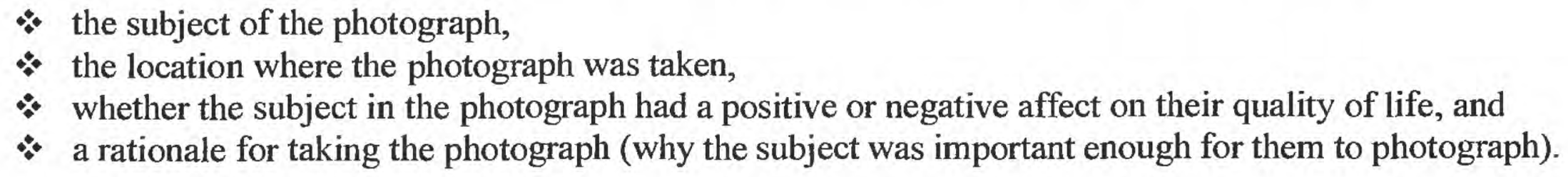

From this information, we were able to create a "big picture" of the study area regarding the element of the natural environment that the respondents felt contributed to their quality of life The respondents were able to take a photograph as well as self describe the area of interest. From this information, we were able to bring together the features in the community that represented both a sense of place and quality of life. A total of 844 photographs were returned and from those photographs 12 categories of special places were identified (Table 3 ). 
Table 3. Categories of special places identified from photos and photo-logs.

\begin{tabular}{|c|c|c|c|c|c|c|}
\hline \multirow{2}{*}{ Photograph features } & \multirow{2}{*}{ Frequency $^{\mathrm{a}}$} & \multirow{2}{*}{$\begin{array}{c}\text { Percent } \\
(\%)\end{array}$} & \multicolumn{4}{|c|}{ Frequency of positive or negative responses } \\
\hline & & & + & - & $+1-$ & No answer \\
\hline $\begin{array}{l}\text { Landscape vistas/open space } \\
\text { - Mountains } \\
\text { - Valleys/pastures } \\
\text { - Cliffs and rock } \\
\text { formations } \\
\text { - "Can see for miles" } \\
\text { - Unobstructive views }\end{array}$ & $(n=108)$ & 13 & 104 & 1 & 3 & - \\
\hline $\begin{array}{l}\text { Community aesthetics } \\
\text { - } \text { Historic homes/ } \\
\text { buildings } \\
\text { - } \text { Tree lined streets } \\
\text { - } \text { Small town } \\
\text { - } \text { atmosphere } \\
\text { - } \text { Comidges } \\
\text { - } \text { Murals } \\
\text { - People } \\
\text { - } \text { Downtown charm } \\
\text { - } \text { Churches }\end{array}$ & $(n=66)$ & 7 & 51 & 6 & 3 & - \\
\hline $\begin{array}{l}\text { Water bodies } \\
\text { - } \text { Streams } \\
\text { - Rivers } \\
\text { - } \text { Hot springs } \\
\text { - Reservoirs } \\
\text { - Lakes }\end{array}$ & $(n=62)$ & 7 & 56 & 2 & 4 & - \\
\hline $\begin{array}{l}\text { Public buildings } \\
\text { - } \text { Airport } \\
\text { - } \text { Fairgrounds } \\
\text { - } \text { Library } \\
\text { - } \text { Schools (K- } \\
\text { 12/colleges and } \\
\text { universities) } \\
\text { - Post office } \\
\text { - Job service } \\
\text { - Office buildings } \\
\text { - } \text { Counitor center } \\
\text { - County annex courthouse }\end{array}$ & $(n=61)$ & 7 & 58 & 2 & 1 & - \\
\hline
\end{tabular}


Table 3. Continued.

\begin{tabular}{|c|c|c|c|c|c|c|}
\hline \multirow{2}{*}{ Photograph features } & \multirow{2}{*}{ Frequency ${ }^{\mathrm{a}}$} & \multirow{2}{*}{$\begin{array}{c}\text { Percent } \\
\text { (\%) }\end{array}$} & \multicolumn{4}{|c|}{ Frequency of positive or negative responses } \\
\hline & & & + & - & $+1-$ & No answer \\
\hline $\begin{array}{l}\text { City parks/fairground } \\
\text { - Ball parks } \\
\text { - Soccer fields } \\
\text { - Local parks (not for } \\
\text { - camping) } \\
\text { - Picnic areas } \\
\text { - Municipal parks (golf } \\
\text { courses and pools } \\
\text { included) }\end{array}$ & $(n=59)$ & 7 & 56 & 2 & 1 & - \\
\hline $\begin{array}{l}\text { Ranching and farming } \\
\text { - } \quad \text { Agriculture } \\
\text { - } \quad \text { Cattle grazing } \\
\text { - } \text { Sheep herding } \\
\text { - Horses } \\
\text { - Rural atmosphere }\end{array}$ & $(n=58)$ & 7 & 52 & 1 & 3 & 2 \\
\hline $\begin{array}{l}\text { Historical and cultural } \\
\text { - The Silverton Railroad } \\
\text { - Archeological aspects } \\
\text { - } \text { Museums } \\
\text { - Performing arts center } \\
\text { Civic centers }\end{array}$ & $(n=57)$ & 7 & 54 & 1 & 2 & - \\
\hline $\begin{array}{l}\text { Trail/natural areas } \\
\text { - Wetlands } \\
\text { - } \text { Swamplands } \\
\text { - } \quad \text { Privatess areas } \\
\text { - } \text { recreations } \\
\text { - } \text { Multiple use area } \\
\text { - Uniking/bike trails } \\
\text { Unzoned areas }\end{array}$ & $(n=53)$ & 6 & 46 & 4 & 3 & - \\
\hline $\begin{array}{l}\text { Retail businesses } \\
\text { - Locally owned } \\
\text { - Major national chain } \\
\text { - } \text { stores } \\
\text { - Malls } \\
\text { - Retels } \\
\end{array}$ & $(n=50)$ & 6 & 28 & 17 & 4 & 1 \\
\hline $\begin{array}{l}\text { Environmental issues } \\
\text { - Air quality } \\
\text { - Noise } \\
\text { - Trash }\end{array}$ & $(n=48)$ & 6 & 13 & 35 & - & - \\
\hline
\end{tabular}


Table 3. Concluded.

\begin{tabular}{|c|c|c|c|c|c|c|}
\hline \multirow{2}{*}{ Photograph features } & \multirow{2}{*}{ Frequency $^{\mathrm{a}}$} & \multirow{2}{*}{$\begin{array}{l}\text { Percent } \\
(\%)\end{array}$} & \multicolumn{4}{|c|}{ Frequency of positive or negative responses } \\
\hline & & & + & - & $+1-$ & No answer \\
\hline $\begin{array}{l}\text { Extractive industries } \\
\text { - } \text { Gas } \\
\text { - } \text { Mining } \\
\text { - Power plants } \\
\text { - } \text { Gravel pits } \\
\text { Pipelines }\end{array}$ & $(n=42)$ & 5 & 15 & 70 & 6 & 1 \\
\hline $\begin{array}{ll}\text { Other }(\text { categories }<5 \%) \\
\text { - } \quad \text { Miscellaneous }(4 \%) \\
\quad \text { State/federal land and } \\
\quad \text { offices }(4 \%) \\
-\quad \text { Wildlife }(3 \%) \\
\text { - } & \text { Streets/roads and } \\
& \text { highways }(2 \%) \\
-\quad & \text { Tourist attractions }(1 \%\end{array}$ & $(\mathrm{n}=115)$ & 14 & 91 & 20 & 2 & 2 \\
\hline Total & 844 & 100 & $6 \overline{39}$ & 165 & $\overline{34}$ & 6 \\
\hline
\end{tabular}

${ }^{a}$ Frequency of the number of photographs in this category.

${ }^{b}$ All numbers may not add up to total $\mathrm{n}$ because some did not provide a response.

\section{Positive and Negative Effects on Quality of Life}

The respondents were asked to report whether the subject of a photograph had either a positive or negative effect on their quality of life (Table 3).

* Landscape vistas views (e.g., open space and unobstructed views) were cited 104 times as having a positive effect on respondents' quality of life.

* New housing developments and subdivisions as well as multi-million doflar homes were cited 54 times as having a negative effect on the respondent's quality of life. Fifteen (27\%) of those same respondents reported that these places were "eating up" valued open space. (71 photographs were taken of housing developments)

- When asked what they most liked or disliked about their community, there were more things respondents liked than disliked. Positive comments focused on community aesthetics and attractions, family experiences, the connection to nature and natural experiences, and living in a beautiful place such as the Colorado Plateau.

* When asked what they most enjoyed about living in the area, the most frequently responses were related to natural $(28 \%)$, social $(20 \%)$, and recreational $(15 \%)$ amenities.

\section{Value Expressions}

For each photograph taken, respondents were asked to tell why the feature was important to their quality of life. We measured these value expressions in two ways. First, from the explanations provided we developed a list of value expressions to capture these rationales. We created this list based on a word count of terms. Second, we categorized the statements into a list of environmental values taken from the 
natural resource literature. Because this question was open-ended, we coded the results and classified them into approximately 14 discrete value categories (Table 4).

Table 4. Value expressions from photo-logs based on list created from all explanations.

\begin{tabular}{|c|c|c|}
\hline Value expressions & $\begin{array}{c}\text { Frequency of terms used to } \\
\text { describe photographs taken } \\
\text { (\# terms }=1,119)(\# \text { photos }=844)\end{array}$ & Percentage \\
\hline $\begin{array}{l}\text { Community } \\
\text { " "sense of" } \\
\text { " safe place to live } \\
\text { - friędly people } \\
\text { " pride } \\
\text { " neighbors }\end{array}$ & 168 & 20 \\
\hline $\begin{array}{l}\text { Nature } \\
\text { = enjoyment } \\
\text { " outdoor activities }\end{array}$ & 162 & 20 \\
\hline $\begin{array}{l}\text { Degradation } \\
\text { - trashy area } \\
\text { - weeds } \\
\text { - pollution (noise, air, water) }\end{array}$ & 118 & 14 \\
\hline $\begin{array}{l}\text { Rural character } \\
\text { - small town charm } \\
\text { = farming/ranching community }\end{array}$ & 114 & 14 \\
\hline $\begin{array}{l}\text { Recreation } \\
\text { - non-consumptive } \\
\text { - consumptive }\end{array}$ & 113 & 13 \\
\hline $\begin{array}{l}\text { Beauty } \\
\text { - aesthetics }\end{array}$ & 100 & 12 \\
\hline $\begin{array}{l}\text { Growth and development } \\
\text { - economic } \\
\text { = new housing } \\
\text { = jobs } \\
\text { = businesses }\end{array}$ & 98 & 12 \\
\hline $\begin{array}{l}\text { Wildlife } \\
\text { " "critters" } \\
\text { = habitat }\end{array}$ & 61 & 7 \\
\hline $\begin{array}{l}\text { Culture/history } \\
\text { - archeological (cultural resources) } \\
\text { - old buildings } \\
\text { - arts and entertainment }\end{array}$ & 52 & 6 \\
\hline $\begin{array}{l}\text { Education } \\
\text { = schools } \\
\text { = opportunities for continued education }\end{array}$ & 40 & 5 \\
\hline
\end{tabular}


Table 4. Concluded.

\begin{tabular}{|l|l|l|l|}
\hline \multicolumn{1}{|c|}{ Value expressions } & $\begin{array}{l}\text { Frequency of terms used to } \\
\text { describe photographs taken } \\
\text { (\# terms =1,119) (\# photos = 844) }\end{array}$ & Percentage \\
\hline $\begin{array}{l}\text { Children } \\
\text { great place to raise kids } \\
\text { - grand kids } \\
\text { - kids playing }\end{array}$ & 35 & 4 \\
\hline $\begin{array}{l}\text { Family } \\
\text { - family experiences ("with the family") }\end{array}$ & 25 & 4 \\
\hline $\begin{array}{l}\text { Affinity for place } \\
\text { - "I love this place" }\end{array}$ & 23 & \\
\hline $\begin{array}{l}\text { Zoning } \\
\text { - examples of poor zoning } \\
\text { - examples of good zoning }\end{array}$ & 10 & \\
\hline
\end{tabular}

When asked to explain why the feature, place, or activity in the photo has an important effect on their quality of life, respondents used terms that could be categorized into a variety of environmental values. The frequency of those values is presented in Table 5.

* For 20\% ( $n=169)$ of photographs taken, respondents reported that the subject was of a practical or "utilitarian" value to them. Examples of comments made included "good lifestyle" or "a nice place to live."

* In $146(17 \%)$ of the photographs taken, respondents described the feature as being "therapeutic." Comments included, "a good place to relax and rejuvenate, and "I like this place because it is very peaceful and calming."

* When describing the condition of the area photographed, $138(16 \%)$ of comments were negative, focusing on zoning issues, new and unsightly housing communities and environmental issues such as trash, noise, and air pollution. 
Table 5. Value expressions from photo-log based on categories from environmental values literature. ${ }^{a}$

\begin{tabular}{|l|c|c|}
\hline \multicolumn{1}{|c|}{ Value } & Frequency $(\mathrm{n}=844)$ & Percentage \\
\hline Social/utilitarian $^{\mathrm{b}}$ & 169 & 20 \\
\hline Natural/naturalistic/therapeutic $^{\mathrm{c}}$ & 146 & 17 \\
\hline Negative $^{\mathrm{d}}$ & 138 & 16 \\
\hline Recreational $^{\mathrm{e}}$ & 127 & 15 \\
\hline Commercial/economic $^{\mathrm{f}}$ & 100 & 12 \\
\hline Aesthetic $^{\mathrm{g}}$ & 86 & 11 \\
\hline Historical/cultural $^{\mathrm{f}}$ & 35 & 4 \\
\hline \begin{tabular}{l|l|} 
Other (humanistic, spiritual, life \\
support)
\end{tabular} & 27 & 3 \\
\hline No answer & 16 & 2 \\
\hline
\end{tabular}

${ }^{\mathrm{a}}$ Categories adapted from King ${ }^{6}$, Kellert ${ }^{7}$, and Manning, et al ${ }^{8}$.

${ }^{b}$ Social/Utilitarian: The practical value of the resources for the benefit of humans. Statements such as: "with family," "with friends," "benefits the community," etc. was included in this category.

${ }^{c}$ Natural/Naturalistic/Therapeutic: The opportunity to maintain or regain physical health or mental well being through contact with nature. A restorative experience - Statements such as: "the ability to get away from it all, "being able to reconnect myself with nature," "offers a sense of peace and tranquility," etc. were included in this category.

${ }^{\mathrm{d}}$ Negative: Any concerns about damage or destruction of the environment; including inappropriate use, pollution (which includes air, land and noise).

${ }^{\mathrm{e}}$ Recreational: The opportunity to participate in any recreational activity in nature, both consumptive and non-consumptive (e.g. hunt, fish, camp, hike, mountain bike, watching wildlife, etc.).

${ }^{f}$ Commercial/Economic: The opportunity to make a profit from nature, including resource use, private land use, timber harvest, etc.

${ }^{g}$ Aesthetic: Primarily interested in the physical attractiveness and symbolic nature of the landscape. Value statements for this category include those describing the scenery, beauty, views, and the joy of living in the area.

historical/Cultural: The opportunity to see and experience nature and the landscape as our ancestors did. This category also included historical landmarks in the community at large as well as cultural events.

i Other (humanistic, spiritual, life support): The ongoing natural "givens" that supports everything else (e.g., rain, sunshine, rivers, open space, blue sky, etc.). Primarily oriented towards a strong emotional affection towards the resources and the landscape.

${ }^{6}$ King, RT. (1966). Wildlife and Man. N.Y. Conservationist 20:8-11

${ }^{7}$ Kellert, S. (1993). The Biological basis for human values of nature. In The Biophilia Hypothesis. Eds. S.R. Kellert and E.O. Wilson, 484-511. Washington, DC.: Island Press.

${ }^{8}$ Manning, R, W. Valliere, and B. Minteer. (1999). Values, Ethics and Attitudes Towards National Forest Management: An Empirical Study. Society of Natural Resources 12:421-436. 


\section{Summary of Findings from Follow-Up Survey: Resident Satisfaction with their Community}

Of the 123 respondents who returned the cameras and photo $\log , 86 \%$ (105) returned the follow-up survey. When considering quality of life issues concerning the Colorado Plateau it is useful for managers to know what residents value about the area, how satisfied they are with the community as a place to live, how important the surrounding landscape is to their quality of life, and how important they believe tourism and public land management is to the economic well being of their communities. The following are some of the most significant findings from this part of the survey. The following is a summary of the first set of questions in the follow up survey.

\section{Section 1: Importance of Surrounding Landscape}

The first question asked the respondents to rate on a scale of $1-5$ how satisfied they were with their community as a place to live (Table 6). Eight out of 10 respondents $(82 \%)$ reported they were satisfied with the community as a place to live.

Table 6. Satisfaction with community $(n=105)$.

\begin{tabular}{|l|c|c|}
\hline & Frequency & Percent (\%) \\
\hline Satisfied & 86 & 82 \\
\hline Neutral & 4 & 4 \\
\hline Dissatisfied & 15 & 14 \\
\hline
\end{tabular}

* On a scale of $1-5$, more than half of respondents (53\%) reported that surrounding landscapes were "extremely important" to their decision to live in the area. And more than a third (36\%) said that it was at least "somewhat important." Only four out of a hundred (4\%) stated that the surrounding landscape not important to their decision to live in the area (Table 7).

Table 7. Importance of surrounding landscape $(n=105)$.

\begin{tabular}{|l|c|c|}
\hline & Frequency & Percent (\%) \\
\hline Extremely important & 84 & 80 \\
\hline Neutral & 84 & 16 \\
\hline Not at all important & 4 & 4 \\
\hline
\end{tabular}

- Relatively few people (30\%) said that they would prefer less tourism in their county than there is now. More than a third of the respondents (35\%) said that they thought that there should be no change in the amount of tourism, and finally, $19 \%$ reported that they would prefer an increase in tourism to their county (Table 8). 
Table 8. Preferences concerning tourism.

\begin{tabular}{|l|c|c|}
\hline & Frequency & Percent (\%) \\
\hline More tourism & 20 & 19 \\
\hline No change & 54 & 51 \\
\hline Less tourism & 31 & 30 \\
\hline
\end{tabular}

* When asked to indicate how important management of public land use was to the economic wellbeing of their community, the most frequent response was that management was extremely important (77\%) (Table 9).

Table 9. Preferences concerning management of public lands.

\begin{tabular}{|l|c|c|}
\hline & Frequency & Percent (\%) \\
\hline Extremely Important & 81 & 77 \\
\hline Neutral & 21 & 21 \\
\hline Not at all important & 2 & 2 \\
\hline
\end{tabular}

The respondents were asked to give an account of the things in their community that they valued. Because this question was open ended, the results were coded and classified into nine categories of interest. The responses in Table 10 represent the categories that received at least one percent of the responses.

The top five things the respondents valued about the community were:

* natural environment (49\%),

remoteness of the area (37\%),

$\therefore$ cultural/historical landmarks (28\%),

- climate $(22 \%)$ and

- recreational opportunities (18\%). 
Table 10. Summary of the things respondents value about their community.

\begin{tabular}{|c|c|c|c|c|}
\hline Variable & $\begin{array}{l}\text { Total frequency of } \\
\text { responses } \\
n=200(\%)\end{array}$ & $\begin{array}{c}\text { First } \\
\text { response } \\
\mathrm{n}=98(\%)\end{array}$ & $\begin{array}{l}\text { Second } \\
\text { response } \\
\mathrm{n}=69(\%)\end{array}$ & $\begin{array}{c}\text { Third } \\
\text { response } \\
\mathbf{n}=33(\%)\end{array}$ \\
\hline $\begin{array}{l}\text { Natural/environment } \\
\text { - Scenery } \\
\text { - Beauty of the area } \\
\text { - Wonderful views } \\
\text { - Natural settings }\end{array}$ & $49(47 \%)$ & $26(25 \%)$ & $18(17 \%)$ & $5(5 \%)$ \\
\hline Remoteness & $37(35 \%)$ & $23(22 \%)$ & $9(9 \%)$ & $5(5 \%)$ \\
\hline $\begin{array}{l}\text { Cultural/hiștorical landmarks } \\
\text { - Anasazi ruins } \\
\text { - Mesa Verde National Park } \\
\text { - The "train" } \\
\text { - Downtown area }\end{array}$ & $28(27 \%)$ & $12(11 \%)$ & $12(11 \%)$ & $4(4 \%)$ \\
\hline $\begin{array}{l}\text { Climate } \\
\text { - Clean air } \\
\text { - Nice weather } \\
\text { - No pollution }\end{array}$ & $22(21 \%)$ & $11(10 \%)$ & $7(7 \%)$ & $4(4 \%)$ \\
\hline $\begin{array}{l}\text { Recreation } \\
\text { - Opportunities to participate in the } \\
\text { outdoors } \\
\text { - Great walking/hiking/biking trails } \\
\text { - Skiing }\end{array}$ & $18(17 \%)$ & $8(8 \%)$ & $6(6 \%)$ & $4(4 \%)$ \\
\hline $\begin{array}{l}\text { Mountains } \\
\text { - Views and recreational opportunities } \\
\text { in the San Juan and La Sal } \\
\text { Mountains } \\
\text { - Vista views }\end{array}$ & $11(10 \%)$ & $7(7 \%)$ & $2(2 \%)$ & $2(2 \%)$ \\
\hline $\begin{array}{l}\text { Agriculture } \\
\text { - Ranching opportunities }\end{array}$ & $9(8 \%)$ & $2(2 \%)$ & $5(5 \%)$ & $2(2 \%)$ \\
\hline $\begin{array}{l}\text { Fish and wildlife } \\
\text { - An abundance of wildlife in the area } \\
\text { - Fishing and hunting opportunities }\end{array}$ & $8(8 \%)$ & $1(1 \%)$ & $3(3 \%)$ & $4(4 \%)$ \\
\hline $\begin{array}{l}\text { Tranquility } \\
\text { - Peaceful place to live } \\
\text { - Wonderful/safe community } \\
\text { Atmosphere }\end{array}$ & $7(7 \%)$ & $2(2 \%)$ & $3(3 \%)$ & $2(2 \%)$ \\
\hline $\begin{array}{l}\text { Educational opportunities } \\
\text { - Good schools } \\
\text { - Educational opportunities } \\
\text { - Cultural experiences through the arts }\end{array}$ & $5(5 \%)$ & $2(2 \%)$ & $2(2 \%)$ & $1(1 \%)$ \\
\hline $\begin{array}{l}\text { Open space } \\
\text { - Undeveloped lands }\end{array}$ & $6(6 \%)$ & $4(4 \%)$ & $2(2 \%)$ & $0(0 \%)$ \\
\hline No answer & $115(109 \%)$ & $7(7 \%)$ & $36(34 \%)$ & $72(68 \%)$ \\
\hline
\end{tabular}


Table 11 presents the percent of the sample that mentioned specific areas as the first, second, or third area in their community that was considered a "special place." Only areas receiving $10 \%$ or higher are listed (Tables 11 and 12).

Table 11. Special places in community.

\begin{tabular}{|l|c|}
\hline Landscapes/vista views/open space & $43 \%$ \\
\hline Water bodies & $39 \%$ \\
\hline Trails & $27 \%$ \\
\hline City/municipal parks & $21 \%$ \\
\hline Downtown/historical areas & $21 \%$ \\
\hline Public buildings & $18 \%$ \\
\hline Federal lands & $13 \%$ \\
\hline Farms/ranches/"my land" & $10 \%$ \\
\hline
\end{tabular}

After each respondent provided a first, second, and third special place in their community, they were then asked to describe the condition of the area. Table 12 shows the descriptions provided for the top seven areas listed by respondents. Only the most frequently provided descriptions are listed in Table 12.

Table 12. Description of special places in the community.

\begin{tabular}{|c|c|}
\hline Category and location & $\begin{array}{l}\text { Most frequent description of the area (rank ordered } \\
\text { by frequency of response) }\end{array}$ \\
\hline $\begin{array}{l}\text { a. Landscape vistas/open space }(n=56) \\
\text { San Juan National Forest/Mountain } \\
\text { La Plata Mountains } \\
\text { Hidden Valley } \\
\text { Animas Valley } \\
\text { All mountains }\end{array}$ & $\begin{array}{l}\text { Well preserved -- } 57 \%(n=2) \\
\text { Scenic } 55 \%-(n=31) \\
\text { Not well preserved -- } 32 \%(n=18) \\
\text { Recreation }-20 \%(n=11) \\
\text { Overused -- } 18 \%(n=10)\end{array}$ \\
\hline $\begin{array}{l}\text { b. Water bodies }(\mathrm{n}=39) \\
\text { Animas River } \\
\text { Delores River } \\
\text { Lemon Reservoir } \\
\text { Navajo Lake }\end{array}$ & $\begin{array}{l}\text { Scenic - } 62 \%(n=24) \\
\text { Not well preserved }-36 \%(n=14) \\
\text { Well preserved }-51 \%(n=20)\end{array}$ \\
\hline $\begin{array}{l}\text { c. Trails - Natural/wilderness areas }(n=22) \\
\text { Animas River Trail } \\
\text { Weminuche Wilderness }\end{array}$ & $\begin{array}{l}\text { Well preserved }-68 \%(n=15) \\
\text { Scenic - } 4 \%(n=14) \\
\text { Recreation }-27 \%(n=6) \\
\text { Remote }--27 \%(n=6) \\
\text { Overused }-22 \%(n=5)\end{array}$ \\
\hline $\begin{array}{l}\text { d. Downtown/hometown }(\mathrm{n}=22) \\
\text { Main Street } \\
\text { Businesses } \\
\text { My home } \\
\text { Tree lined streets }\end{array}$ & $\begin{array}{l}\text { Well preserved }-\%(n=10) \\
\text { Scenic -- } 6 \%(n=8) \\
\text { Not well preserved -- } 36 \%(n=8) \\
\text { Recreation }-31 \%(n=7)\end{array}$ \\
\hline e. Other $(n=22)$ & Well preserved $-77 \%(n=17)$ \\
\hline
\end{tabular}


Table 12. Concluded.

\begin{tabular}{|c|c|}
\hline Category and location & $\begin{array}{l}\text { Most frequent description of the area (rank ordered } \\
\text { by frequency of response) }\end{array}$ \\
\hline $\begin{array}{l}\text { Ranchlands } \\
\text { Farm/agricultural lands }\end{array}$ & $\begin{array}{l}\text { Scenic }-5 \%(n=10) \\
\text { Not well preserved -- } 31 \%(n=7) \\
\text { Remote -- } 31 \%(n=7)\end{array}$ \\
\hline $\begin{array}{l}\text { f. City/municipal parks/recreational areas }(\mathrm{n}=21) \\
\text { Carpenter Park } \\
\text { City Park } \\
\text { Farmington Aquatic Center } \\
\text { Mancos Town Park }\end{array}$ & $\begin{array}{l}\text { Well preserved }-62 \%(n=13) \\
\text { Scenic }-38 \%(n=8) \\
\text { Not well preserved -- } 38 \%(n=8) \\
\text { Recreation }-3 \%(n=7) \\
\text { Cultural }-19 \%(n=4)\end{array}$ \\
\hline $\begin{array}{l}\text { g. Public buildings }(\mathrm{n}=17) \\
\text { San Juan Community College } \\
\text { Fort Lewis College } \\
\text { Churches } \\
\text { Durango Art Center }\end{array}$ & $\begin{array}{l}\text { Well preserved }-35 \%(n=6) \\
\text { Scenic }--29 \%(n=5) \\
\text { Cultural -- } 24 \%(n=4) \\
\text { Not well preserved -- } 24 \%(n=4) \\
\text { Recreation }--29 \%(n=5)\end{array}$ \\
\hline
\end{tabular}

\section{Section 2: Special Places}

Because people often develop strong feelings about certain outdoor places that have special meaning and importance to them, we wanted to learn about how the respondents felt about their special places. The respondents were asked to identify one or two areas in southwestern Colorado and northwestern New Mexico that have special personal meaning or importance to them. For each of the places they were asked to report the name and location (Table 13) and that things/activities they did at each location (Table 14) and finally, they were asked to give the reason that the place had special meaning to them (Table 15).

Table 13. Special places listed by three or more respondents (total and county distribution).

\begin{tabular}{|l|c|}
\hline Special places & Total $(\mathrm{n}=81)$ \\
\hline La Plata Mountains/Canyon & $9(11 \%)$ \\
\hline San Juan National Forest & $16(20 \%)$ \\
\hline Navajo Lake/Dam & $12(15 \%)$ \\
\hline Delores River & $8(10 \%)$ \\
\hline Weminuche Wilderness & $7(9 \%)$ \\
\hline Mesa Verde & $7(9 \%)$ \\
\hline Groundhog Lake/Reservoir & $4(5 \%)$ \\
\hline Piedra River & $3(4 \%)$ \\
\hline Williams Lake & $3(4 \%)$ \\
\hline Vallecito Lake & $3(4 \%)$ \\
\hline
\end{tabular}

After each respondent provided one or two special places they were asked to describe the things they do in their special places. Table 13 lists the activities provided by the respondents. Only the most frequently provided activities are listed in the table. 
Table 14. Special activiites listed by three or more respondents (total and county distribution).

\begin{tabular}{|c|c|c|c|c|c|c|c|c|}
\hline Activity & $\begin{array}{c}\text { Total } \\
\mathrm{n}=332\end{array}$ & $\begin{array}{c}\text { San } \\
\text { Miguel } \\
\mathrm{n}=3\end{array}$ & $\begin{array}{c}\text { San Juan } \\
\text { (CO) } \\
\mathrm{n}=16\end{array}$ & $\begin{array}{c}\text { Delores } \\
\mathrm{n}=6\end{array}$ & $\begin{array}{c}\text { Montezuma } \\
\mathrm{n}=81\end{array}$ & $\begin{array}{l}\text { La Plata } \\
\mathrm{n}=134\end{array}$ & $\begin{array}{c}\text { Archuleta } \\
\mathrm{n}=41\end{array}$ & $\begin{array}{c}\text { San Juan } \\
\text { (NM) } \\
\mathrm{n}=52\end{array}$ \\
\hline $\begin{array}{l}\text { Recreation (1) } \\
\text { Hike } \\
\text { Picnic } \\
\text { Camp } \\
\text { Ride horses } \\
\text { Swim } \\
\text { General }\end{array}$ & $\begin{array}{l}n=86 \\
(26 \%)\end{array}$ & $\begin{array}{c}n=2 \\
(50 \%)\end{array}$ & $\begin{array}{c}\mathrm{n}=4 \\
(25 \%)\end{array}$ & $\begin{array}{c}n=2 \\
(33 \%)\end{array}$ & $\begin{array}{l}n=13 \\
(16 \%)\end{array}$ & $\begin{array}{l}n=44 \\
(33 \%)\end{array}$ & $\begin{array}{l}n=11 \\
(27 \%)\end{array}$ & $\begin{array}{l}n=12 \\
(23 \%)\end{array}$ \\
\hline $\begin{array}{l}\text { Recreation (2) } \\
\text { Hunt } \\
\text { Fish }\end{array}$ & $\begin{array}{l}\mathrm{n}=69 \\
(21 \%)\end{array}$ & $\begin{array}{c}n=1 \\
(25 \%)\end{array}$ & - & $\begin{array}{c}n=4 \\
(66 \%)\end{array}$ & $\begin{array}{l}n=14 \\
(17 \%)\end{array}$ & $\begin{array}{l}n=23 \\
(17 \%)\end{array}$ & $\begin{array}{l}\mathrm{n}=10 \\
(24 \%)\end{array}$ & $\begin{array}{l}n=17 \\
(32 \%)\end{array}$ \\
\hline $\begin{array}{l}\text { Environmental } \\
\text { Scenery } \\
\text { viewing } \\
\text { Wildlife/ } \\
\text { nature } \\
\text { photography } \\
\text { Cultural/ } \\
\text { historical } \\
\text { viewing }\end{array}$ & $\begin{array}{l}\mathrm{n}=95 \\
(29 \%)\end{array}$ & $\begin{array}{c}n=1 \\
(25 \%)\end{array}$ & $\begin{array}{c}n=4 \\
(25 \%)\end{array}$ & - & $\begin{array}{l}n=34 \\
(42 \%)\end{array}$ & $\begin{array}{l}n=35 \\
(26 \%)\end{array}$ & $\begin{array}{l}\mathrm{n}=10 \\
(24 \%)\end{array}$ & $\begin{array}{l}n=11 \\
(21 \%)\end{array}$ \\
\hline $\begin{array}{l}\text { Personal } \\
\text { Relax } \\
\text { Family/ } \\
\text { friends } \\
\text { related }\end{array}$ & $\begin{array}{l}n=82 \\
(25 \%)\end{array}$ & - & $\begin{array}{c}n=8 \\
(50 \%)\end{array}$ & - & $\begin{array}{l}n=20 \\
(24 \%)\end{array}$ & $\begin{array}{l}n=32 \\
(23 \%)\end{array}$ & $\begin{array}{l}\mathrm{n}=10 \\
(24 \%)\end{array}$ & $\begin{array}{l}n=12 \\
(23 \%)\end{array}$ \\
\hline
\end{tabular}

The next question in this section asked the respondents to give the reason that this place had special meaning to them (Table 15). Because this question was open-ended the responses were coded into categories. Responses that drew less than $1 \%$ of the total are not listed in the following table. 
Table 15. Significance of special places.

\begin{tabular}{|c|c|c|c|c|c|c|c|c|}
\hline Reason & $\begin{array}{l}\text { Total } \\
n=280\end{array}$ & $\begin{array}{l}\text { San } \\
\text { Miguel } \\
n=2\end{array}$ & $\begin{array}{l}\text { San } \\
\text { Juan } \\
(\mathrm{CO}) \\
\mathrm{n}=8\end{array}$ & $\begin{array}{l}\text { Delores } \\
\mathrm{n}=12\end{array}$ & $\begin{array}{l}\text { Montezuma } \\
n=60\end{array}$ & $\begin{array}{l}\text { La Plata } \\
\mathrm{n}=116\end{array}$ & $\begin{array}{l}\text { Archuleta } \\
\mathrm{n}=39\end{array}$ & $\begin{array}{l}\text { San Juan } \\
\text { (NM) } \\
\mathrm{n}=48\end{array}$ \\
\hline $\begin{array}{l}\text { Environmental } \\
\text { Scenery } \\
\text { Aesthetics } \\
\text { Vista views } \\
\text { Pastoral scenes } \\
\text { Climate } \\
\text { Rural atmosphere } \\
\text { Wildlife/nature } \\
\text { viewing opportunities }\end{array}$ & $\begin{array}{l}n=116 \\
(41 \%)\end{array}$ & - & $\begin{array}{l}n=5 \\
(4 \%)\end{array}$ & $\begin{array}{l}n=2 \\
(2 \%)\end{array}$ & $\begin{array}{l}n=24 \\
(21 \%)\end{array}$ & $\begin{array}{l}n=51 \\
(44 \%)\end{array}$ & $\begin{array}{l}n=15 \\
(13 \%)\end{array}$ & $\begin{array}{l}n=19 \\
(16 \%)\end{array}$ \\
\hline $\begin{array}{l}\text { Social/community } \\
\text { Home } \\
\text { My hometown } \\
\text { This is where I grew } \\
\text { up } \\
\text { Family/friends } \\
\text { related } \\
\text { Memories } \\
\text { Small town charm } \\
\text { Safe place to raise } \\
\text { kids } \\
\text { Good schools }\end{array}$ & $\begin{array}{l}n=23 \\
(8 \%)\end{array}$ & - & $\begin{array}{l}n=1 \\
(4 \%)\end{array}$ & $\begin{array}{l}n=1 \\
(4 \%)\end{array}$ & $\begin{array}{l}n=5 \\
(22 \%)\end{array}$ & $\begin{array}{l}n=7 \\
(30 \%)\end{array}$ & $\begin{array}{l}n=3 \\
(13 \%)\end{array}$ & $\begin{array}{l}n=6 \\
(26 \%)\end{array}$ \\
\hline $\begin{array}{l}\text { Cultural/historical } \\
\text { "Lots of history here" } \\
\text { Archeological sites } \\
\text { Aztec ruins } \\
\text { Heritage }\end{array}$ & $\begin{array}{l}n=54 \\
(19 \%)\end{array}$ & $\begin{array}{l}n=1 \\
(2 \%)\end{array}$ & $\begin{array}{c}\mathrm{n}=1 \\
(2 \%)\end{array}$ & $\begin{array}{l}n=2 \\
(4 \%)\end{array}$ & $\begin{array}{l}n=18 \\
(33 \%)\end{array}$ & $\begin{array}{l}n=24 \\
(44 \%)\end{array}$ & $\begin{array}{l}n=12 \\
(22 \%)\end{array}$ & $\begin{array}{l}n=10 \\
(19 \%)\end{array}$ \\
\hline $\begin{array}{l}\text { Recreational } \\
\text { Hiking } \\
\text { Municipal Parks } \\
\text { Camping }\end{array}$ & $\begin{array}{l}n=41 \\
(15 \%)\end{array}$ & $\begin{array}{l}n=1 \\
(2 \%)\end{array}$ & $\begin{array}{l}n=1 \\
(2 \%)\end{array}$ & $\begin{array}{l}n=4 \\
(10 \%)\end{array}$ & $\begin{array}{l}n=4 \\
(10 \%)\end{array}$ & $\begin{array}{l}n=18 \\
(44 \%)\end{array}$ & $\begin{array}{l}n=5 \\
(12 \%)\end{array}$ & $\begin{array}{l}n=9 \\
(22 \%)\end{array}$ \\
\hline $\begin{array}{l}\text { Personal/emotional } \\
\text { Remote } \\
\text { Peaceful place to be } \\
\text { Tranquil } \\
\text { Go here to relax } \\
\text { Escape from the } \\
\text { world here }\end{array}$ & $\begin{array}{l}n=46 \\
(16 \%)\end{array}$ & - & - & $\begin{array}{l}n=3 \\
(7 \%)\end{array}$ & $\begin{array}{l}n=9 \\
(20 \%)\end{array}$ & $\begin{array}{l}n=16 \\
(35 \%)\end{array}$ & $\begin{array}{l}\mathrm{n}=4 \\
(9 \%)\end{array}$ & $\begin{array}{l}n=4 \\
(9 \%)\end{array}$ \\
\hline
\end{tabular}


Table 1.6 presents the results for the final question in this section: "Do you know the land owner of this area?"

Table 16. Knowledge of land ownership.

\begin{tabular}{|c|c|c|c|c|c|c|c|c|}
\hline Land ownership & $\begin{array}{c}\text { Total } \\
\mathrm{n}=19\end{array}$ & $\begin{array}{c}\text { San } \\
\text { Miguel } \\
\mathrm{n}=16\end{array}$ & $\begin{array}{c}\text { San } \\
\text { Juan } \\
(\mathrm{CO}) \\
\mathrm{n}=20\end{array}$ & $\begin{array}{c}\text { Delores } \\
\mathrm{n}=7\end{array}$ & $\begin{array}{c}\text { Montezuma } \\
n=49\end{array}$ & $\begin{array}{c}\mathrm{La} \\
\text { Plata } \\
\mathrm{n}=76\end{array}$ & $\begin{array}{c}\text { Archuleta } \\
\mathrm{n}=41\end{array}$ & $\begin{array}{c}\text { San Juan } \\
\text { (NM) } \\
\mathrm{n}=34\end{array}$ \\
\hline $\begin{array}{l}\text { Private } \\
\text { Private }\end{array}$ & $\begin{array}{c}31 \\
(16 \%)\end{array}$ & $\begin{array}{c}1 \\
(6 \%)\end{array}$ & $\begin{array}{c}4 \\
(20 \%)\end{array}$ & $\begin{array}{c}2 \\
(28 \%)\end{array}$ & $\begin{array}{c}11 \\
(22 \%)\end{array}$ & $\begin{array}{c}12 \\
(16 \%)\end{array}$ & $\begin{array}{c}6 \\
(15 \%)\end{array}$ & $\begin{array}{c}2 \\
(6 \%)\end{array}$ \\
\hline County & $\begin{array}{c}4 \\
(2 \%)\end{array}$ & - & - & $\begin{array}{c}1 \\
(14 \%)\end{array}$ & $\begin{array}{c}1 \\
(2 \%)\end{array}$ & $\begin{array}{c}3 \\
(4 \%)\end{array}$ & - & - \\
\hline $\begin{array}{l}\text { State } \\
\text { State forest } \\
\text { School trust }\end{array}$ & $\begin{array}{c}14 \\
(7 \%)\end{array}$ & $\begin{array}{c}2 \\
(12 \%)\end{array}$ & $\begin{array}{c}1 \\
(5 \%)\end{array}$ & $\begin{array}{c}1 \\
(\%)\end{array}$ & $\begin{array}{c}3 \\
(6 \%)\end{array}$ & $\begin{array}{c}6 \\
(8 \%)\end{array}$ & $\begin{array}{c}3 \\
(7 \%)\end{array}$ & $\begin{array}{c}3 \\
(9 \%)\end{array}$ \\
\hline $\begin{array}{l}\text { Federal } \\
\text { Forest Service } \\
\text { Fish \& Wildlife } \\
\text { Service } \\
\text { BLM } \\
\text { Park Service } \\
\text { BOR }\end{array}$ & $\begin{array}{c}114 \\
(59 \%)\end{array}$ & $\begin{array}{c}11 \\
(69 \%)\end{array}$ & $\begin{array}{c}9 \\
(45 \%)\end{array}$ & $\begin{array}{c}3 \\
(43 \%)\end{array}$ & $\begin{array}{c}27 \\
(55 \%)\end{array}$ & $\begin{array}{c}49 \\
(64 \%)\end{array}$ & $\begin{array}{c}25 \\
(61 \%)\end{array}$ & $\begin{array}{c}20 \\
(59 \%)\end{array}$ \\
\hline Don't know & $\begin{array}{c}22 \\
(11 \%)\end{array}$ & $\begin{array}{c}2 \\
(12 \%)\end{array}$ & $\begin{array}{c}2 \\
(10 \%)\end{array}$ & - & $\begin{array}{c}6 \\
(12 \%)\end{array}$ & $\begin{array}{c}5 \\
(7 \%)\end{array}$ & $\begin{array}{c}4 \\
(10 \%)\end{array}$ & $\begin{array}{c}9 \\
(26 \%)\end{array}$ \\
\hline Other & $\begin{array}{c}7 \\
(4 \%)\end{array}$ & - & $\begin{array}{c}4 \\
(20 \%)\end{array}$ & - & $\begin{array}{c}1 \\
(2 \%)\end{array}$ & $\begin{array}{c}2 \\
(3 \%)\end{array}$ & $\begin{array}{c}2 \\
(5 \%)\end{array}$ & - \\
\hline
\end{tabular}

\section{Section 3: Personal Activities}

One of the goals of this study was to become aware of the ways in which local residents used public lands for personal activities. The respondents were asked to limit their responses to activities they did on public lands in San Miguel, Dolores, Montezuma, La Plata, San Juan (CO), Archuleta, and San Juan (NM) Counties. The respondents were asked to report the number of times, ranging from one time to six or more times, they participated in an activity that year. Table 17 presents the activities that received at least one percent or more of all responses. The top three activities mentioned by respondents are Viewing scenery $(87 \%)$, watching wildlife $(87 \%)$, and overnight camping or day picnicking $(84 \%)$. 
Table 17. Personal uses of public lands.

\begin{tabular}{|c|c|c|c|c|c|c|c|c|}
\hline \multirow[t]{2}{*}{ Activity } & \multicolumn{8}{|c|}{$\begin{array}{l}\text { Percent who participated in this activity this year } \\
\qquad(\mathrm{n}=105)\end{array}$} \\
\hline & 0 & 1 & 2 & 3 & 4 & 5 & $6+$ & N/A \\
\hline $\begin{array}{l}\text { Collecting forest products for personal use } \\
\text { (firewood, Christmas trees, etc.) }\end{array}$ & 50 & 13 & 14 & 8 & 2 & 6 & 6 & 1 \\
\hline Overnight camping or day picnicking & 10 & 2 & 8 & 13 & 7 & 4 & 54 & 2 \\
\hline Viewing scenery & 10 & 0 & 1 & 5 & 4 & 4 & 73 & 4 \\
\hline $\begin{array}{l}\text { Motorized travel (vehicle, boat, } \\
\text { snowmobile, etc) }\end{array}$ & 20 & 2 & 4 & 6 & 7 & 4 & 58 & 0 \\
\hline $\begin{array}{l}\text { Non-motorized travel (hiking, biking, river } \\
\text { floating) }\end{array}$ & 20 & 0 & 6 & 5 & 7 & 4 & 57 & 2 \\
\hline Off-road vehicle riding & 71 & 3 & 4 & 5 & 3 & 1 & 11 & 2 \\
\hline $\begin{array}{l}\text { Hunting (big game, small game, } \\
\text { waterfowl) }\end{array}$ & 64 & 8 & 3 & 2 & 6 & 1 & 14 & 2 \\
\hline Fishing & 47 & 4 & 6 & 8 & 7 & 1 & 26 & 1 \\
\hline Watching wildlife & 13 & 6 & 10 & 3 & 3 & 62 & 3 & \\
\hline $\begin{array}{l}\text { Viewing interpretive displays, attending } \\
\text { programs }\end{array}$ & 31 & 14 & 11 & 13 & 11 & 2 & 14 & 2 \\
\hline Driving for pleasure & 18 & 2 & 9 & 12 & 9 & 5 & 43 & 1 \\
\hline $\begin{array}{l}\text { Winter sports (skiing, sledding, cross } \\
\text { country) }\end{array}$ & 41 & 3 & 7 & 3 & 4 & 6 & 35 & 1 \\
\hline
\end{tabular}

Respondents were presented with a series of organizations and were asked to indicate whether or not they were a member of that organization or group (Table 18). The top three responses were membership in a church or a religious organization (42\%), property owner or taxpayer association $39 \%$ and national or regional environmental or preservation group $30 \%$. 
Table 18. Ogranizational membership.

\begin{tabular}{|c|c|c|}
\hline & \multicolumn{2}{|c|}{$\mathrm{n}(\%)$} \\
\hline Variable & Yes & No \\
\hline Hunting/fishing clubs & $16(15 \%)$ & $89(85 \%)$ \\
\hline $\begin{array}{l}\text { Farming/ranching/agricultural organizations } \\
\text { (Cattlemen's Association, wool growers etc.) }\end{array}$ & $16(15 \%)$ & $89(85 \%)$ \\
\hline $\begin{array}{l}\text { National or regional environmental preservation groups } \\
\text { (SUWA, Sierra Club, etc.) }\end{array}$ & $31(30 \%)$ & $74(70 \%)$ \\
\hline Local environmental preservation groups & $28(27 \%)$ & $77(73 \%)$ \\
\hline Wildlife habitat protection groups & $28(27 \%)$ & $77(73 \%)$ \\
\hline $\begin{array}{l}\text { Non-motorized recreation groups } \\
\text { (mountain biking, hiking, climbing, etc.) }\end{array}$ & $18(16 \%)$ & $88(8 \%)$ \\
\hline Off-road vehicle organizations & $6(6 \%)$ & $94(99 \%)$ \\
\hline Property owner or taxpayer association & $37(39 \%)$ & $63(66 \%)$ \\
\hline $\begin{array}{l}\text { Community service organization (Lions, Kiwanis, Rotary, } \\
\text { etc) }\end{array}$ & $26(25 \%)$ & $79(75 \%)$ \\
\hline $\begin{array}{l}\text { Community business and economic development } \\
\text { organizations Chamber of Commerce, Business Roundtable, } \\
\text { etc) }\end{array}$ & $18(17 \%)$ & $87(82 \%)$ \\
\hline Developers or real estate organizations & $3(3 \%)$ & $102(97 \%)$ \\
\hline Church or religious organizations & $42(40 \%)$ & $63(60 \%)$ \\
\hline Other & $29(27 \%)$ & $76(72 \%)$ \\
\hline None & $10(9 \%)$ & $95(90 \%)$ \\
\hline
\end{tabular}

\section{Section 4: Survey Respondent Characteristics}

In this section we report socio-demographic information about the study population. Below are statistics that summarize characteristics of the survey respondents (Table 19).

* Out of the 105 respondents who answered the follow-up survey $65 \%$ were male and $35 \%$ were female.

* The majority of the respondents identified themselves as non-Hispanic (87\%) white Americans $(97 \%)$ between the ages of 20-86 years old. More than half (53\%) were between 40-59 years old; $33 \%$ were over the age of 60; and thirteen percent were in the 20-39 category.

Eighty percent of the respondents had two or more years of college training and education and $58 \%$ completed college or had an advanced degree. 
* When asked about their occupational status, the three most frequent response were professional/technical (28\%), retired (28\%), and self employed (22\%). The average, self reported, household income, before taxes, was between $\$ 50-60,000$. Sixty-five percent stated that their income was between $\$ 30,000-59,999 ; 34 \%$ earned income of $\$ 60,000$ or more; and only $1 \%$ reported earning $\$ 29,000$ or less.

- Respondents have lived in the study area an average of 20 years (minimum of 1 year and maximum of more than 60 years); $40 \%$ lived in La Plata county, 23\% lived in Montezuma County and $16 \%$ lived in San Juan County, NM

Table 19. Follow-up survey demographic variables.

\begin{tabular}{|c|c|c|}
\hline i & $n=105$ & Percent \\
\hline $\begin{array}{l}\text { Your age: } \\
20-29 \\
30-39 \\
40-49 \\
50-59 \\
60-69 \\
70-79 \\
80-89 \\
\text { No answer }\end{array}$ & $\begin{array}{r}1 \\
13 \\
32 \\
23 \\
23 \\
11 \\
1 \\
1\end{array}$ & $\begin{array}{r}1 \\
12 \\
30 \\
22 \\
22 \\
11 \\
1 \\
1\end{array}$ \\
\hline $\begin{array}{l}\text { Please identify your gender: } \\
\text { Male } \\
\text { Female }\end{array}$ & $\begin{array}{l}67 \\
38\end{array}$ & $\begin{array}{l}64 \\
36\end{array}$ \\
\hline $\begin{array}{l}\text { What ethinicity do you consider yourself? } \\
\text { Hispanic or Latino } \\
\text { Not Hispanic or Latino } \\
\text { No Answer }\end{array}$ & $\begin{array}{r}7 \\
86 \\
12\end{array}$ & $\begin{array}{r}7 \\
82 \\
11\end{array}$ \\
\hline $\begin{array}{l}\text { What is the name of your county? } \\
\text { San Miguel } \\
\text { San Juan (CO\%) } \\
\text { Dolores } \\
\text { Montezuma } \\
\text { La Plata } \\
\text { Archuleta } \\
\text { San Juan (NM\%) }\end{array}$ & $\begin{array}{r}1 \\
5 \\
2 \\
24 \\
42 \\
14 \\
17 \\
\end{array}$ & $\begin{array}{r}1 \\
5 \\
2 \\
23 \\
40 \\
13 \\
16\end{array}$ \\
\hline $\begin{array}{l}\text { How long have you lived in this county? } \\
<1 \text { year } \\
1-10 \text { years } \\
11-20 \text { years } \\
21-30 \text { years } \\
31-40 \text { years } \\
41-50 \text { years } \\
51-60 \text { years } \\
>60 \text { years }\end{array}$ & $\begin{array}{r}1 \\
43 \\
27 \\
14 \\
2 \\
8 \\
4 \\
6\end{array}$ & $\begin{array}{r}1 \\
41 \\
26 \\
13 \\
2 \\
8 \\
4 \\
6 \\
\end{array}$ \\
\hline
\end{tabular}


Table 19. Concluded.

\begin{tabular}{|c|c|c|}
\hline Variable & $n=105$ & Percent \\
\hline $\begin{array}{l}\text { How long have you lived in this county? } \\
<1 \text { year } \\
1-10 \text { years } \\
11-20 \text { years } \\
21-30 \text { years } \\
31-40 \text { years } \\
41-50 \text { years } \\
51-60 \text { years } \\
>60 \text { years }\end{array}$ & $\begin{array}{r}1 \\
43 \\
27 \\
14 \\
2 \\
8 \\
4 \\
6\end{array}$ & $\begin{array}{r}1 \\
41 \\
26 \\
13 \\
2 \\
8 \\
4 \\
6\end{array}$ \\
\hline $\begin{array}{l}\text { What is your highest level of education? } \\
\text { Some high school } \\
\text { Completed high school } \\
\text { Technical training } \\
\text { Some college/two year degree } \\
\text { Completed college } \\
\text { Some graduate work } \\
\text { An advanced degree } \\
\text { Other } \\
\text { No answer }\end{array}$ & $\begin{array}{r}3 \\
9 \\
7 \\
23 \\
27 \\
18 \\
16 \\
1 \\
1\end{array}$ & $\begin{array}{r}3 \\
9 \\
7 \\
22 \\
26 \\
17 \\
15 \\
1 \\
1\end{array}$ \\
\hline $\begin{array}{l}\text { Which category best fits your occupational status } \\
\text { Student } \\
\text { Trade worker } \\
\text { Office worker } \\
\text { Homemaker } \\
\text { Professional/Technical } \\
\text { Self-employed } \\
\text { Agriculture } \\
\text { Unemployed } \\
\text { Retired } \\
\text { No answer }\end{array}$ & $\begin{array}{r}2 \\
3 \\
3 \\
5 \\
30 \\
23 \\
6 \\
1 \\
30 \\
2\end{array}$ & $\begin{array}{r}2 \\
3 \\
3 \\
5 \\
28 \\
22 \\
6 \\
1 \\
28 \\
2\end{array}$ \\
\hline $\begin{array}{l}\text { What is your appproximate annual family income before taxes? } \\
\text { Less than } \$ 10,000 \\
\$ 10,000-19,999 \\
\$ 20,000-29,999 \\
\$ 30,000-39,999 \\
\$ 40,000-49,999 \\
\$ 50,000-59,999 \\
\$ 60,000-69,999 \\
\$ 70,000-79,999 \\
\$ 80,000-89,999 \\
\$ 90,000-99,999 \\
\$ 100,000-109,999 \\
\$ 110,000 \text { and above } \\
\text { No answer }\end{array}$ & $\begin{array}{r}4 \\
9 \\
4 \\
13 \\
17 \\
15 \\
7 \\
16 \\
5 \\
3 \\
2 \\
2 \\
8\end{array}$ & $\begin{array}{r}4 \\
8 \\
4 \\
12 \\
16 \\
14 \\
7 \\
15 \\
5 \\
3 \\
2 \\
2 \\
7\end{array}$ \\
\hline
\end{tabular}




\section{Conclusions}

In the fall of 1998 we conducted a mail survey to examine quality of life issues on the Colorado Plateau. We intended to provide evidence of: (a) what constitutes quality of life among resident populations, and (b) what critical areas, elements, and special places are essential to retain a certain quality of life. The research objective was to gather information to determine what landscape and ecosystem elements are important or essential to residents of the Colorado Plateau. As expected, we found that scenic/vista views and recreational experiences are important to local residents, however, these features when combined with children, family and friends were fundamental to their quality of life on the Colorado Plateau.

\section{Managerial Implications}

While information on quality of life issues is useful, it may be equally useful to explore the underlying ideas that drive such issues. This would allow managers and policymakers to fully understand what is considered to be important values and how these'values might change over time. This research focused on the aspects of the landscape on the Colorado Plateau that contributed to the quality of life and sense of place for the local residents. The results from this study attempted to assist natural resource managers in making informed decisions about the development of future management plans and practices that will impact local communities and their residents. We believe that by focusing on the environmental values that contribute to sense of place this research has the potential to assist natural resource managers in developing policies that will result in publicly acceptable and viable politically viable programs.

The job of natural resource managers and policy makers is growing increasingly more and more complex because of the conspicuous connections between natural resource and social science. Environmental attitudes and values have shifted significantly in recent decades. The public and other stakeholders increasingly demand collaborative approaches to natural resource planning and management; and Resource management paradigms are shifting from traditional multiple use to ecosystem based approaches.

Managing natural resources in ways that are responsive to changing social conditions is the main challenge faced by managers today. The method described in this report is an approach for the assessment of a broad range of trends in the social environment. This study attempted to illustrate that not all aspects of quality of life are easily described in words. The photographs allowed the researcher to "see" the landscape through the eyes of the respondents. An important component of this method is that it provides an excellent opportunity for communication with land use managers and planners. 